$\underline{\underline{\beta}=-5}$

\title{
Physico-chemical characteristics and fatty acid profile of allium fistulosum vegetable plant
}

\author{
Adeniyi Adeyeye \\ Department of Chemical Sciences, Oduduwa University, Ipetumodu, PMB 5533, Ile-Ife, Osun State, Nigeria \\ E-mail: niyade2016@gmail.com
}

\begin{abstract}
The physicochemical properties of the plant and the fatty acid profile of the plant oil of Allium fistulosum have been determined using standard methods of the AOAC. The proximate composition gave moisture content of $89.55 \%$, ash content $0.82 \%$, crude oil $0.64 \%$, crude protein $1.82 \%$, crude fibre $1.65 \%$ and carbohydrate $5.54 \%$. The most abundant fatty acids in decreasing order of abundance were linoleic $(52.87 \%)>$ oleic $(17.57 \%)>$ palmitic $(9.80 \%)>$ stearic $(8.81 \%)>$ linolenic $(2.88 \%)>$ palmitoleic $(2.84 \%)>$ myristic $(1.28 \%)>$ behenic (1.23\%). Others with concentrations less than $1.00 \%$ are lauric, arachidonic, behenic and lignoceric acids. Linoleic and oleic acids were the most abundant of the total fatty acids and also of the total unsaturated fatty acids with the two totaling $70.44 \%$ of all fatty acids. Palmitic and stearic acids were the two most abundant saturated fatty acids, totaling $18.61 \%$ of all fatty acids. The total unsaturated fatty acids $(77.35 \%)$ predominated the total saturated $(22.63 \%)$, while the percentage poly-unsaturated $(56.34 \%)$ was far greater than mono-unsaturated $(21.04 \%)$. The high level of essential fatty acids in the plant oil is an advantage in food consumption and the good total unsaturated/saturated (PS) ratio makes the fruit oil nutritionally very useful to be adopted for domestic purposes.
\end{abstract}

Keywords:Spring Onion; Allium Fistulosum Plant; Proximate Composition; Fatty Acid Profile; Total Unsaturated/Total Saturated (P/S) Ratio.

\section{Introduction}

The onion (Allium) family contains several species, distributed all over various countries of the world. These various species are valued for their distinctive and peculiar pungency and flavour which improve the taste of food generally. Allium cepa, the bulb type, is the most prominent of the onions. This bulb onion and the green leafy type are used domestically almost on daily basis in every home and are essential ingredients of Nigerian diet (NIHORT, 1986). In some rural parts of northern Nigeria, dried fermented preparations from the green leaves are used to flavour food, especially when fresh onions are no more available (Bello et. al., 2013). The leafy type, Allium fistulosum, commonly called spring onion, Welsh onion, or Japanese bunching onion, is a clumping, slowly-spreading, evergreen perennial type that is primarily grown as a vegetable for its tasty onion-flavored leaves. It is called "àlùbósà eléwé" (i.e. leafy onion) in Yoruba language of southwestern Nigeria. The species is very similar in taste and odour to the related common onion, Allium cepa, but does not develop bulbs. It rather possesses hollow leaves (fistulosum means "hollow") and scapes. A. fistulosum can multiply by forming perennial evergreen clumps (Thompson, 1995). It is also grown in bunches in gardens as an ornamental plant. Superficially there is a strong resemblance to Allium cepa, but Allium fistulosum does not develop a bulb, although some slight thickening of the base of the pseudostem may occur. Its foliage leaves are somewhat roundish in cross-section, not flattened adaxially.

Allium fistulosum probably originated from northwestern China. The crop is grown throughout the world, in a wide range of climatic conditions from temperate to tropical, but the main area of cultivation remains eastern Asia, especially in China and Japan. Elsewhere, it is mainly a crop of home gardens. In Africa, it is locally important only and is reported from Sierra Leone, Ghana, Cameroon, Congo, DR Congo, Sudan, Kenya, Zambia and Zimbabwe, and also from Nigeria (Oyen \& Messiaen, 2004). Its growth spreads across many areas of the southwest in Nigeria, but it is particularly grown in İréé town, where it is found in gardens around homes, apart from plantations in farms, hence the appellation "İréé àlálùbósà", (meaning Ìréé, the onion growing town). It is fast growing in nature and very easy to grow. It is harvested within three to four months after planting. Welsh onion is grown for its green leaves, which are used in salad, or added to flavour soup and other dishes. In the Brazzaville-Kinshasa area (i. e. Congo Brazzaville and DR Congo) whole plants are harvested and eaten as a boiled vegetable. In Java in South-East Asia, the plants are also eaten whole, either steamed or after being heated over fire for a short time, and in Japan the seedlings are used in special dishes (Oyen \& Messiaen, 2004).

In the processed form, A. fistulosum has not been of much application until recent times. Its product is mainly used as an additive to preprocessed food such as instant noodles. The young inflorescence is sometimes deep-fried and eaten as a snack (Oyen \& Messiaen, 2004). The plant is said to reduce or prevent termite infestation in gardens. Apart from this, a lot of therapeutic qualities are attributed to it, especially in Chinese medicine. It has been credited with amazing powers to improve eyesight, and to enhance recovery from common colds, headaches, wounds and festering sores, while diluted pressed juice is used against aphids. It is also believed to improve the functioning of internal organs and metabolism (Oyen \& Messiaen, 2004). Consumption of onion is associated with a reduction in blood 
lipids, cholesterol and platelet activity, contributing to decreased risk of cardiovascular diseases and, thereby, prolonging life (Augusti, 1990). With so much uses of A. fistulosum, much less attention has been paid to its chemical and fatty acids contents. This report, therefore, focuses on the chemical composition and fatty acid profile of A. fistulosum plant as available in Nigeria, to be able to reveal its usefulness and importance in the diet of man.

\section{Materials and methods}

\subsection{Sample collection and preparation}

Fresh samples of Allium fistulosum vegetable plant were obtained from a plantation in Iree, a town in Osun State in the southwest of Nigeria, known for its cultivation. The samples were cleaned, dried and pulverized, ready for further analyses.

\subsection{Proximate analysis}

Proximate composition, including moisture, ash, crude fat, crude protein and crude fibre were determined in accordance with the Official Methods of the Association of Official Analytical Chemists (AOAC, 2012). Moisture content was determined by oven drying of 200g of each sample to a constant weight at $105^{\circ} \mathrm{C}$. Crude protein content was determined using the Kjeldahl method, while crude fat content was determined by Soxhlet method using n-hexane as solvent. Ash content was determined gravimetrically after ignition at $550^{\circ} \mathrm{C}$. Carbohydrate content was calculated by difference. All analyses were carried out in triplicates.

\subsection{Fatty acid analysis}

The fatty acids of the sample oil were converted to their methyl esters and analysed using a PYE Unicam 304 gas chromatograph fitted with a flame ionization detector and PYE Unicam computing integrator. Nitrogen was used as the carrier gas. The column initial temperature was $150^{\circ} \mathrm{C}$ rising at $5^{\circ} \mathrm{C}$ min- 1 to a final temperature of $220^{\circ} \mathrm{C}$. The injection port and detector temperatures were maintained at $220^{\circ} \mathrm{C}$ and $250^{\circ} \mathrm{C}$ respectively. The peaks were identified by comparing with peaks of standard fatty acid methyl esters under the same operating conditions (Adeyeye et al., 2020).

\section{Results and discussion}

\subsection{Proximate analysis}

The proximate composition of Allium fistulosum is as presented in Table 1. The plant had a high moisture content of $89.55 \%$, similar to what was obtained for many edible vegetables, such as Allium cepa (white) 89.62\% and Allium cepa (red) $88.48 \%$ (Lawal \& Matazu, 2015), Amaranthus hybridus (85.40\%) and Corchorus olitorius (86.35) (Adeyeye et al., 2018a) and Solanum nodiflorum, Launaea taraxacifolia, Senecio biafrae and Cucurbita maxima, 90.89\%, 89.76\%, 90.65\% and $89.25 \%$ respectively (Adeyeye et al., 2018b). The high moisture content makes it to aid digestion process, thereby, contributing to good and healthy living. Water is the most important nutrient and the most abundant substance in the human body. It comprises about three quarters of the human mass and is a major component in every cell. It is also the containing medium for electrolytes and all other ions throughout the human body. (Adeyeye et al., 2018a).

Table 1: Proximate Composition of. Allium Fistulosum Vegetable Plant

\begin{tabular}{ll}
\hline Proximate analysis & Table 1: Proximate Composition of. Allium \\
\hline Moisture & $89.55 \pm 0.15$ \\
Dry matter & $10.45 \pm 0.08$ \\
Ash & $0.82 \pm 0.15$ \\
Crude protein & $1.82 \pm 0.02$ \\
Crude oil & $0.64 \pm 0.04$ \\
Crude fibre & $1.65 \pm 0.05$ \\
Carbohydrate & $5.54 \pm 0.16$ \\
\hline
\end{tabular}

The plant had a crude oil content of $0.64 \%$. This value is similar to that of purple onion $(0.60 \%)$, reported by Chukwu et al., (2008) and those between $0.67 \%$ and $0.84 \%$ reported for five onion varieties (Dinkecha \& Muniye, 2017). The very low oil content of this plant is an advantage for the obese and others with some other related diseases. Health disorders such as appendicitis, haemorrhoids, gallstones, heart diseases and constipation are either corrected or treated by copious consumption of vegetables, such as Allium fistulosum, because of the low fat contents (Adeyeye et al., 2018a). However, the low oil content is not in favour of its use as a source of oil for commercial purposes.

The ash content of the plant was $0.82 \%$. This is within the range of values (between $0.77 \%$ and $2.37 \%$ ) for four Allium varieties (Akinwande \& Olatunde, 2015), but higher than $0.55 \%$ and $0.50 \%$ reported for white and purple onions (Chukwu et al., 2008). The low ash content of the plant is indicative of the low level of its mineral elements.

The plant had a crude protein content of $1.82 \%$. This is higher than $1.20 \%$ and $1.30 \%$ reported for Allium cepa white and purple bulbs respectively (Chukwu et al., 2008), but lower than 3.22\% and 3.02\% reported for white and red Allium cepa respectively (Lawal \& Matazu, 2015). Protein is an important source of amino acids. Apart from playing a part in the organoleptic properties of food, it is also required for the formation of enzymes and hormones. It is an essential food component needed in our bodies to repair, regulate and protect itself. In addition, it aids in the formation of antibodies that enable the body to fight infection (Brosman, 2003, Orech et al., 2005). On the other hand, protein deficiency causes growth retardation, muscle wasting, oedema, abnormal swelling of the belly etc (Granner et al., 1990). The very low protein content of this plant shows that it cannot be used as a good source of protein for man.

The crude fibre content of the plant was $1.65 \%$. This value is higher than $0.56 \%$ and $0.40 \%$ reported for white and purple onions by (Chukwu et al., 2008) and $0.73 \%$ for red Allium cepa (Odebunmi et al., 2007), but lower than $3.83 \%$ and $2.83 \%$ reported for white and 
red onions (Allium cepa) by Lawal \& Matazu (2015) and those between 3.8\% and 5.1\% reported for five varieties onions by Dinkecha \& Muniye (2017). Dietary fibre helps to lower the risk of coronary heart diseases, hypertension, diabetes, colon and breast cancer, piles and appendicitis (Omale \& Ugwu 2011). It is useful for maintaining bulk motility and increasing intestinal peristalsis by surface extension of the food in the intestinal tract. It is also necessary for a healthy condition, curing of nutritional disorders and for food digestion (Pereira et al., 2004).

This plant had a low carbohydrate content of $6.54 \%$. This value is lower than $9.60 \%$ and $11.25 \%$ reported for purple and white onions (Allium cepa) by Chukwu et. al., (2008), but higher than $3.46 \%$ for Corchorus olitorius and $5.54 \%$ for Amaranthus hybridus, two leafy vegetables in Nigeria (Adeyeye et al., 2018a). Low carbohydrate contents are a common phenomenon with vegetables. Because vegetables also generally have low fat and protein contents, as is the case with this plant, they contribute very little to the energy values of meals. Hence, the leafy vegetables are ideal for the obese and diabetics who can satisfy their appetites without consuming much carbohydrate and, at the same time, control their weight and health.

\subsection{Fatty acid profile}

The fatty acid content of the sample of Allium fistulosum plant oil is given in table 2. Twelve fatty acids were identified in the sample. The most abundant fatty acids were linoleic acid (52.87\%) and oleic acids (17.57\%), both adding up to $70.44 \%$ of the total fatty acids of the sample. Other fatty acids present in the order of abundance were palmitic $(9.80 \%)$, stearic $(8.81 \%)$, linolenic $(2.88 \%)$, palmitoleic $(2.84 \%)$, myristic $(1.28 \%)$ and behenic $(1,23 \%)$. Others of concentration less than $1.00 \%$ were lauric, arachidonic, erucic and lignoceric acids. The plant oil had a higher degree of unsaturation (77.38\%) than saturation (22.63\%). The linoleic acid content of the oil, (52.87\%), is higher than 32.648\% recorded for garden egg (Adeyeye et. al., 2020), 12.65\% for onion bulb (Bello et al., 2013), 37.32\% for Corchorus olitorius and 33.44\% for Amaranthus hybridus (Adeyeye et al., 2018a), but lower than 67.59\% for Solanium elaeagnifolium (Feki et al., 2013). Linoleic acid, the most abundant fatty acid in the oil, is of great importance as it prevents cardiovascular disorders such as coronary heart diseases and atherosclerosis, and also guides against high blood pressure (Adeyeye et al., 2018c). It helps to relieve rough and flaky skin and maintain smooth and moist skin. Its derivatives also serve as structural components of the plasma membrane and as precursors of some metabolic regulatory compounds (Omode et al., 1995; Ariffin et al., 2009).

Table 2: Fatty Acid Composition of Spring Onion (Allium Fistulosum) Plant Oil

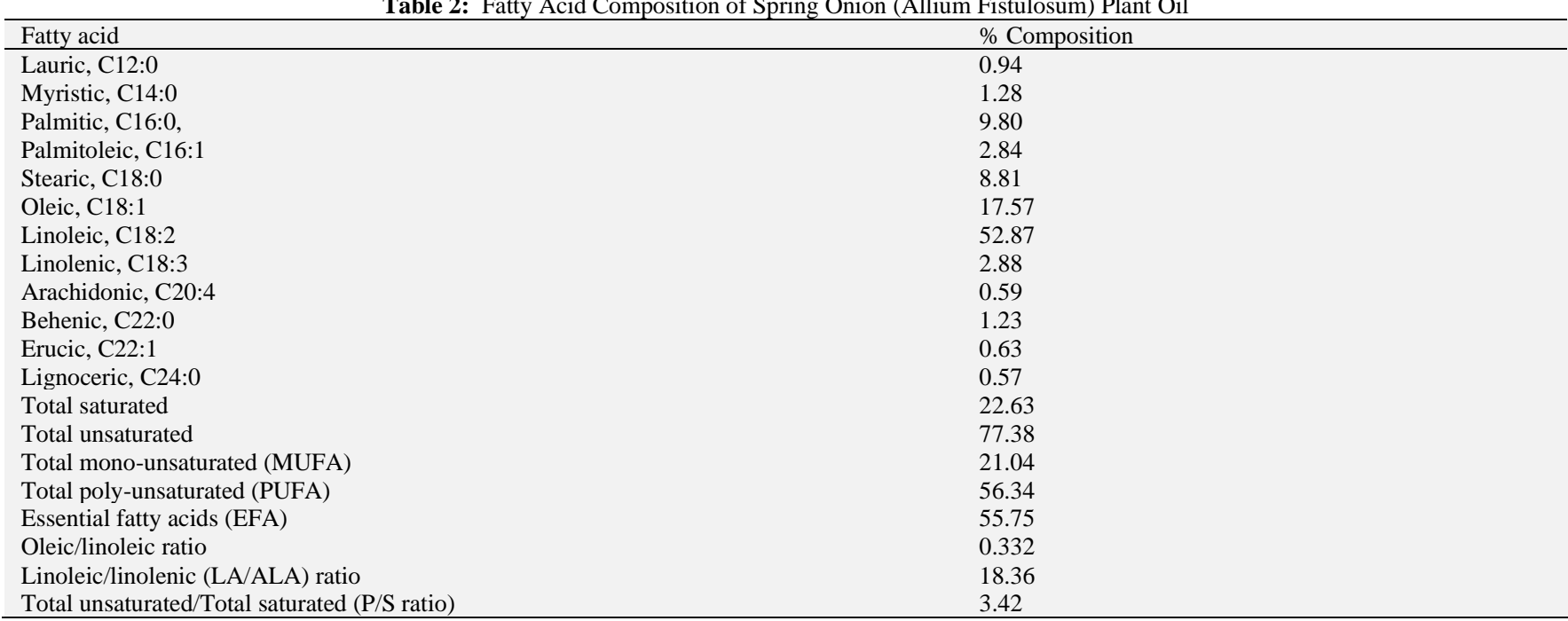

The good concentration of oleic acid in the oil, (17.57\%), is also of great importance as it plays a fundamental role in the prevention of cardiovascular diseases. It is also very important in nervous cell construction (Cobertt, 2003; Nasri et al., 2005). With oleic and linoleic acids having the highest percentage concentrations, the oil can be regarded as an oleic-linoleic oil. The presence of some level of linolenic acid in the oil sample is also of nutritional importance. It is an essential polyunsaturated fatty acid used in the biosynthesis of arachidonic acid and thus some prostaglandins and also thromboxane (Alozie et al., 1978; Nelson \& Cox, 2005). Both arachidonic acid and prostaglandins are required for cell growth and maintenance (Nelson \& Cox, 2005). The high percentage of linoleic and linolenic acids combined gives the plant oil an advantage as these fatty acids are essential in the diet of man, but they cannot be produced in the body and need to be supplied from foodstuffs for the proper functioning of the body system. The presence of erucic acid makes the fruit oil important as it serves as a precursor in bio-diesel production (David et al., 2006). The availability of arachidonic acid is also of dietary importance as it serves as a precursor of prostaglandin and thromboxane biosynthesis (Nelson \& Cox, 2005). Alium fistulosum plant oil was characterized by a reasonable polyunsaturated/saturated $(\mathrm{P} / \mathrm{S})$ ratio of 3.42 . This ratio determines the detrimental effects of dietary fats. A high $\mathrm{P} / \mathrm{S}$ ratio favours the reduction of serum cholesterol and atherosclerosis and the prevention of heart diseases (Oomah et al., 2000). The low oleic/linoleic ratio of this oil reduces its use for deep frying because of its low stability for the purpose (Branch et al., 1990).

Many of the saturated fatty acids present in the plant oil have some important uses. Lauric acid is believed to have antimicrobial properties (Muhammad \& Ajiboye, 2010). It can undergo $\beta$-oxidation to produce energy and can also be stored in adipose tissues (Nelson \& Cox, 2005). Myristic acid is used as a raw material in cosmetics production. Palmitic acid is the first fatty acid produced during fatty acid synthesis and from which longer chain fatty acids can be synthesized (Muhammad \& Ajiboye, 2010; Murray et al., 2000). Stearic acid is useful mainly as a surfactant, emulsifier, and thickener when added to cosmetics and personal care products. As a thickener or hardener, stearic acid is added to things like soaps, candles, plastics, oil pastels, etc, when it helps to harden the product and to retain its shape. In addition to functioning as a surfactant to help wash away excess oil and dirt from the skin, it also protects skin's surface against water loss and helps shore up skin's protective barrier. The presence of behenic acid in the oil, (1.23\%), may not be beneficial as the acid is not favorably disposed to the activities of the digestive enzymes in the digestion of food in man and animals (Balogun \& Fetuga, 
1985). On the other hand, the high degree of unsaturation of the oil reduces its probability of aiding heart diseases (Ajewole \& Adeyeye 1991).

\section{Conclusion}

The proximate composition of the fresh plant and fatty acid profile of the oil of Allium fistulosum from Nigeria was reported in this study. The proximate composition compared well with those of some other allium species in literature. The plant gave a higher percentage of unsaturated fatty acids compared to saturated fatty acids, and also gave a good level of essential fatty acids, a value greater than $50 \%$ of the total fatty acids content of the plant oil. These values make the plant nutritionally rich and valuable. The low oil content, however, is a disadvantage for its commercial production. Otherwise, the oil would have been good as an alternative to other common vegetable oils for domestic and/or industrial purposes, thereby adding greater value to the plant in the market.

\section{References}

[1] Adeyeye A, Ayodele OD., Akinnuoye GA., Sulaiman W. (2018a). Proximate composition and fatty acid profiles of two edible leafy vegetables in Nigeria. American Journal of Food, Nutrition and Health, (2): 51-55.

[2] Adeyeye A, Ayodele OD, AkinnuoyeGA (2018b). Evaluation of the nutritional composition of some less common edible leafy vegetables in Nigeria. American Journal of Food Science and Nutrition, 5(1): 26-31.

[3] Adeyeye A, Akinnuoye GA, Akinyode OA. (2018c). Proximate composition and fatty acid profile of the seeds of Andrographis paniculata. Am. Jour. Food Sci. \& Nutri. Res. 5(3):71-75.

[4] Adeyeye A, Salami-Adeniyi A, Sulaiman WK, Akinyode OA. (2020).Proximate composition and fatty acid profile of garden egg (Solanum aethiopicumL) fruit. International Journal of Food Science and Nutrition 5(2): 09-13.

[5] Ajewole K \&Adeyeye A. (1991). Seed oil of white star apple (Chrysophyllum albidum) - physicochemical characteristics and fatty acid composition. Journal of the Science of Food and Agriculture 54: 313-315.https://doi.org/10.1002/jsfa.2740540219.

[6] Akinwande, BA. and Olatunde, SJ. (2015). Comparative evaluation of the mineral profile and other selected components of onion and garlic. International Food Research Journal 22(1): 332-336.

[7] Alozie SO, Sharma RP, Salunkhe DK. (1978). Inhibition of Rat Cholinesterase Soenzymesin Vitro and In Vivo by Potato Alaloill and Chaconine (Utah State University, Logan, UT 84322, USA: Interdepartmental Toxicology Programme).

[8] AOAC. (2012). Official Methods of Analysis, Association of Official Analytical Chemist, 19th edition, Washington, D C.

[9] Ariffin AA, Bakar J, Tan CP, Rahaman RA, Karim R, Loi CC. (2009). Essential fatty acids of pataya (dragon fruit) seed oil. Food Chemistry. 114: 561-564. https://doi.org/10.1016/j.foodchem.2008.09.108.

[10] Augusti KT (1990). Therapeutic and medicinal values of onion and garlic. In: Rabinowitch H, Brewster J (eds) Onion and allied crops Vol III. CRC Press, Boca Raton, FL, USA, pp 94-108.

[11] Balogun AM, Fetuga BL. (1985). Fatty acid composition of seed oils of some members of the leguminosae family. Food Chem. 17(3): 175-182 https://doi.org/10.1016/0308-8146(85)90066-4.

[12] Bello, MO., Olabanji, IO., Abdul-Hammed, M. and Okunade, T.D. (2013).Characterization of domestic onion wastes and bulb (Allium cepa L.): fatty acids and metal contents. International Food Research Journal 20(5): 2153-2158.

[13] Branch WD, Nakayama T, Chennan MS. (1990). Fatty acid variation among US runner type peanut cultivars. J Am Oil Chem Soc. 67: 591593.https://doi.org/10.1007/BF02540772.

[14] Brosman J. (2003). Interogram amino acid transport and its regulation. Journal of Nutrition. 133: 20682072.https://doi.org/10.1093/jn/133.6.2068S.

[15] Chinedu SN, Olasumbo AC, Eboji OK, Emiloju OC, Arinola OK, Dania DI, et al. (2011). Proximate and phytochemical analyses of Solanum aethiopicum L. and Solanum macrocarpon L. fruits. Res. J. Chem. Sci. 1(3): 63-71.

[16] Chukwu, EC, Azonwu O, Osakwe, J.A. and Eke J. (2008). Onion (Allium cepa), its physicochemical properties, fungal flora and shelf life in PortHarcourt. Journal of Research in Bioscience 4(2): 82-88.

[17] Cobertt P. (2003). It is time for an oil change. Opportunities for high oleic vegetable oils. Information. 14: 480-481.

[18] David J, Anneken SB, Christoph R, Fieg G, Steinberner U, Westfechtel A, et al. (2006). Fatty acids. Ullmann's Encyclopaedia of Industrial Chemistry.https://doi.org/10.1002/14356007.a10_245.pub2.

[19] Dinkecha K and Muniye M. (2015). Proximate composition and physicochemical properties of different released and improved onion (Allium cepa L.) bulb varieties. Food Science and Quality Management 67: 1 - 7.

[20] Feki H, Koubaa I, Jaber Makni HJ and Damak M, (2013). Characteristics and chemical composition of Solanum elaeagnifoliumseed oil. ARPN Journal of Engineering and Applied Sciences8(9): 708.

[21] Granner DK, Rodwell VW, Mayes PA, Murray, RK. (1990). In: Harper's Biochemistry. A Lange Medical Book. 25th Edition. McGraw-Hill.

[22] Grubben, GJH. \& Denton, OA. (Editors). 2020. PROTA (Plant Resources of Tropical Africa / Ressourcesvégétales de l'Afriquetropicale), Wageningen, Netherlands. <http://www.prota4u.org/search.asp>.

[23] Lawal, A. and Matazu, SS. (2015). Comparative studies of white and red Allium cepa cultivated in Sokoto, Nigeria. ChemSearch Journal 6(2): 14 20.

[24] Muhammad NO, Ajiboye BO. Nutrients composition of Rana galamensis. (2010). African J. Food Sci. Technol. 1(1): 27-30.

[25] Murray RK, Granner DK, Mayer PA, Rodwel VW. (2000). In: Harper's Biochemistry. A Lange Medical Book. 20th Edition. McGraw-Hill.

[26] Nasri N, Khalil A, Fady B, Triki S. (2005). Fatty acids from seeds of Pinus pinea L. Composition and population profiling. Phytochemistry. 66: 1729-1735.https://doi.org/10.1016/j.phytochem.2005.05.023.

[27] Nelson DC, Cox MM. (2005). Lehninger Principles of Biochemistry (4th Ed.) W. H. Freeman \& Co. New York.

[28] NIHORT, (1986). National Institute of Horticultural Research and Technology. Advances in fruit and vegetable research at NIHORT Nigeria: A commemorative publication to mark the 11th anniversary of NIHORT.

[29] Odebunmi, EO., Oluwaniyi, OO., Sanda, AM. and Kolade, BO. (2007). Nutritional composition of selected tubers and root crops used in Nigerian food preparations. International journal of chemistry. 17(1): 37-43.

[30] Omale J, Ugwu CE. (2011).Comparative studies on the protein and mineral composition of some selected Nigerian vegetables. Afri. J. Fd. Sci. 5(1): 22-25.

[31] Omode AA, Fatoki OS, Olaogun KA. (1995). Physicochemical properties of some under-exploited and non-conventional oil seeds. J. Agric. Food Chem. 43: 2850-2853. https://doi.org/10.1021/jf00059a015.

[32] Oomah DB, Ladet S, Godfrey VD, Liang J and Giarard B. (2000). Characteristics of raspberry (Rubus idaeusL.) seed oil. J. Food Chem. 69: 187193.https://doi.org/10.1016/S0308-8146(99)00260-5.

[33] Orech FO, Akenga T, Ochora J, Friis H, Aagaard Hassen J. (2005). Potential toxicity of some traditional leafy vegetables consumed in Nyang'oma Division, Western Kenya. Afri. J. Food, Agric. Nutri. and Dev. 5(1): 9-14.

[34] Oyen, LPA. \& Messiaen, CM., (2004). Allium fistulosum L. [Internet] Record from PROTA4U. Grubben, GJH. \& Denton, OA. (Editors). PROTA (Plant Resources of Tropical Africa / Ressourcesvégétales de l'Afriquetropicale), Wageningen, Netherlands. $<$ http://www.prota4u.org/search.asp>. 
[35] Pereira MA, O’Reilly E, Augustsson K, Fraser, GE, Goldbourt U, Heitmann BL. Etc. (2004). Dietary fibre and risk of coronary heart disease: A pooled analysis of cohort studies. Archives of Int. Med. 164(4): 370-376.https://doi.org/10.1001/archinte.164.4.370.

[36] Thompson, Sylvia (1995). The Kitchen Garden. Bantam Books, New York. 